\section{Aydın İlinde Yetiştirilen Siyah Alaca İneklerde Karşılaştırmalı Vücut Kondisyon Skoru İle NEFA Düzeyleri Arasındaki İlişkinin Araştırılması}

\section{Investigation on The Relationship Between Comperative Body} Condition Score and Nefa Levels Among Holstein Cows Raised in

\section{Aydin Municipality}

\section{Özet}

Bu çalışma, Siyah Alaca ineklerde vücut kondisyon skoru ile NEFA düzeyleri arasındaki ilişkinin belirlenmesi amacıyla yapılmıştır. Araştırmanın hayvan materyalini, Aydın ili Bozdoğan ilçesinde mevcut süt sı ğırcılı̆̆ı işletmelerinde yetiştirilen, Adnan Menderes Üniversitesi Veteriner Fakültesi Büyük Hayvan Kliniklerine gelen ve Aydın ili özel işletmelerine kayıtlı 4-6 yaş aralığında ve geçiş döneminde (doğum öncesi -3 . haftadan, buzağılama sonrası +3 . haftaya kadar olan süreçte) olan 21 baş Siyah Alaca gebe inek oluşturmuştur. Araştırmada Siyah Alaca inekler VKS bakımından da 3 farklı gruba ayrılmıştır: $2<\mathrm{VKS}<3,3<\mathrm{VKS}<4$ ve $4 \leq \mathrm{VKS}$. Çalışma kapsamında hayvanların vücut kondisyon skorlaması kuru dönemde (buzağılama öncesi -2 hafta; $15 \pm 2$. günlerde) ve puerperal dönemde (postpartum +2 . haftada; 15 \pm 3 . Günlerde) gerçekleştirilmiştir. İneklerin vücut kondisyon skorunun (VKS) tespit edilmesinde 5'lik sistem kullanılmıştır. Yine aynı dönemlerde hayvanlarda negatif enerji dengesinin etkisini belirlemek amacıyla serum biyokimyasal analizler gerçekleştirilmiştir. Pre-partum dönemde yapılan ölçümlerde NEFA konsantrasyonu $0.48 \pm 0.089 \mathrm{mmol} / \mathrm{L}$ olarak, buzağılama sonrası 0 ile 15 günlük süreçte ise $1.01 \pm 0.189 \mathrm{mmol} / \mathrm{L}$ olarak tespit edilmiştir $(\mathrm{P}<0.01)$. VKS sınıflarına göre NEFA ortalamaları, buzağılama öncesi ve sonrası dönemlerde sırasıyla $0.52 \pm 0.104 \mathrm{mmol} / \mathrm{L}$ ile $0.35 \pm 0.149 \mathrm{mmol} / \mathrm{L}$ olarak tespit edilmiştir. Buzağılama sonrası dönemde ise vücut kondisyonu artan ineklerde NEFA değerlerinde bir artış olduğu tespit edilmiştir. Esterleşmemiş serbest yağ asidi konsantrasyonları üzerine VKS etkisi değerlendirildiğinde ise istatistik bakımdan önemli bir ilişkiye rastlanmamıştır $(\mathrm{P}>0.05)$. VKS ile NEFA arasındaki korelasyonlar Pearson Korelasyon Testi yardımıyla hesaplanmıştır. Yapılan hesaplamalar sonucunda VKS ile NEFA arasında düşük ve negatif yönlü bir korelasyon (-0.24) saptanmıştır $(\mathrm{P}>0.05)$. Sonuç olarak, farklı fizyolojik yapı sergileyen ineklerin mevcut metabolik profili değerlendirilerek enerji dengelerinin tespit edilmesi ve bu şekilde bazı metabolik ve üretim problemlerinin önüne geçilmesi mümkün olabilir.

Anahtar Kelimeler: Siyah Alaca, Vücut Kondisyon Skoru, Esterleşmemiş Yağ Asidi
Araşturma Makalesi

Deniz Alıç Ural ${ }^{1}$

Songül Erdoğan ${ }^{2}$

${ }^{1}$ Veteriner Fakültesi, Çiftlik Hayvanları, Adnan Menderes Üniversitesi

${ }^{2}$ Veteriner Fakültesi, İç Hastalıkları Anabilim Dalı Adnan Menderes Üniversitesi

İletişim (Correspondence)

Deniz Alıç Ural alicdeniz@gmail.com

Makale Bilgisi Geliş: 05-04-2018

Kabul: 26-04-2018

Copyright ${ }^{\circledR} 2018$ JAVST 


\begin{abstract}
This study was conducted to determine the relationship between body condition score and NEFA levels in Holstein cows. The animal material of the study was collected at the 4- to 6-year-old age (from -3 weeks before birth to +3 days after birth) in Aydın province Bozdoğan province, which is grown in dairy cattle businesses, Adnan Menderes University Veterinary Faculty, week), the head of the Black Pied Prenatal cow was formed. In the study Black Holstein cows were divided into 3 groups according to BCS: $2<\mathrm{BCS}<3,3<\mathrm{BCS}<4$ and 4 BCS. In the study, the body condition scores of the animals were carried out during the dry period (pre-calving 2 weeks, $15 \pm 2$ days) and puerperal period (postpartum 2 weeks, $15 \pm 3$ days). A 5-point system was used when the cow's body condition score (BCS) was determined. In the same period, serum biochemical analyzes were carried out to determine the effect of negative energy balance in animals. NEFA concentration was $0.48 \pm 0.089 \mathrm{mmol} / \mathrm{L}$ in pre-partum period and $1.01 \pm 0.189 \mathrm{mmol} / \mathrm{L}$ in $0-15$ days after calving $(\mathrm{P}<0.01)$. According to BCS classes, NEFA averages were found to be $0.52 \pm 0.104 \mathrm{mmol} / \mathrm{L}$ and $0.35 \pm 0.149 \mathrm{mmol} / \mathrm{L}$ in prepartum and postpartum periods, respectively. In the postpartum period, it was determined that there was an increase in NEFA values in cows with increased body condition. The effect of BCS on non-esterified fatty acid concentrations was not found significant $(\mathrm{P}>0.05)$. The relation between BCS and NEFA were investigated by Pearson correlation. The low and negatif correlations (-0.24) was found between BCS and NEFA (P>0.05). As a result, it may be possible to determine energy balances by evaluating the current metabolic profile of cows exhibiting different physiological structure and thus avoiding some metabolic and production problems.
\end{abstract}

Key words: Holstein-Friesian, Body Condition Score, Non-esterified fatty acid

\title{
Giriş
}

Süt sığırcılığında karlılığı etkileyen en önemli faktörlerden birisi üreme performansıdır. Son 30-40 ylllık periyotta genetik ilerleme ve süt verimi artışına paralel olarak (Patton vd., 2006), ilk tohumlamadaki gebelik oranının \%65'ten \%45’e düştüğ̈̈ (Butler, 1998), gebelik başına yapılan tohumlama sayısının 1.62 'den 2.91'e (Silvia, 1998) yükseldiği görülmektedir. Ayrıca üreme problemleri nedeniyle ortaya çıkan kaybın inek başına yıllık $52 \$$ seviyelerinde olduğu bildirilmektedir (Bellows vd., 2002).

Süt sığırlarında üreme performansı son yıllarda verimin artmasıyla birlikte düşme eğilimi göstermiştir (Butler, 1998). Bunun süt verimi bakımından sağlanan genetik ilerleme ile ilgili olabileceği düşünülmektedir. Doğum sonrası laktasyonla birlikte süt ineklerinde besin madde gereksinmeleri ciddi boyutta yükselmektedir. Ancak, gereksinmelerdeki artşa karşın yem tüketim kapasitesinin sınırlı olması negatif enerji bilançosunu doğurmaktadır.
Negatif enerji dengesinin şiddeti, hayvanın süt verimi, sütün kompozisyonu ve hayvanın yem tüketim kapasitesiyle değişmektedir. Negatif enerji dengesine (NED) bağlı olarak süt ineklerinde vücut rezervlerinin yoğun kullanımı söz konusudur. Tamminga vd., (1997) laktasyonun ilk 8 haftasında $41.6 \mathrm{~kg}$ ağırlık kaybeden ineklerde kaybın 30.9 kg'ını yağ ve 4.6 kg'ının ise protein olduğunu bildirmiştir. $\mathrm{Bu}$ metabolik yük hayvanlarda üreme performansının bozulmasında etkili olmaktadır (Görgülü vd., 2011). Yüksek verimli hayvanlarda kızgınlık süresi (6.2 saate karşı 10.9 saat, Lopez vd., 2004) ile kızgınlık belirleme oranı düşmekte (1985: \%50.9, 1999: \%41.5, Washburn vd., 2002), servis periyodu uzamakta (Roche vd., 2000, Gong 2002), anöstrus görülme sıklı̆g yükselmekte (Mwaanga ve Janowski, 2000), oositlerin döllenme kabiliyetleri düşmekte, ikizlik artmakta (Wiltbank, 2006) ve embriyonal kayiplar yüksek (Silke vd., 2002) olmaktadır. 
Hayvanc1llğı gelişmiş olan ülkelerde vücut kondisyon puanı sürü yönetim programlarında süre gelen bir uygulama olarak karşımıza çıkmaktadır. Vücut kondisyon skoru (VKS), süt ineklerinin gerek vücutlarındaki yağ düzeylerini ölçmeye yarayan ve gerekse enerji dengesini gösteren dolaylı ölçütlerden biri olarak kullanılmaktadır (Kellogg, 1914; Yaylak ve Kaya, 2000; Çitil ve Uzlu, 2005; Varışlı ve Tekin, 2011). Bunun yanında, ineklerin VKS'sinden sağlik, verim ve metabolik profilleri hakkında bilgi edinmek üzere bir ölçüt olarak da yararlanılmaktadır (Coşkun, 1997; Roche vd., 2009; Amaral-Phillips, 2010).

Kellogg (1914) VKS'nin, bir süt ineğinin deri altı yağ dokusu miktarının ölçümüne dayalı olduğunu bildirirken, Defra (2001) VKP ölçümlerinin ekonomik besleme, kaliteli üretim ve hayvan refahı arasındaki dengenin sağlanması amacıyla yapıldığını ifade etmiştir. Yaylak ve Kaya (2000) ise VKS'nin süt ineklerinin gereksinimlerine yönelik bir yemleme programını düzenlemeye yardımcı olduğunu bildirmiştir. Bunun yanı sıra süt ineklerinde laktasyon dönemlerine bağlı olarak vücut kondisyonlarında meydana gelen değişimin tespiti ve uygun kondisyonun sürdürülmesinde bir ölçüm sistemi olarak VKS'nin yararlı olduğu da yapılan tespitler arasında yer almıştır (Varışlı ve Tekin, 2011; Ayaşan vd., 2012).

Son 40 yıldan beri özellikle yüksek süt verimine sahip ırkların yetiştiricilikte kullanılmasıyla hayvan başına alınan süt miktarı iki katından daha fazla oranlara çıkmış olmakla birlikte (Oltenacu, 2007), erken laktasyon döneminde (0-70. Gün) yüksek süt verimini karşılamaya yetmeyen enerji açı̆̆ının vücut yağları ve kaslardan giderilmeye çalışıldı 1 tespit edilmiştir (Suriyasathaporn, 1999; Bobe vd., 2004; Leslie vd., 2004; Kehrli vd., 2006; LeBlanc, 2010; Gumen vd., 2011). Ayrıca süt verimindeki artışı sağlamak için yapılan genetik seleksiyonlar, yem tüketim potansiyeli ile erken laktasyon dönemi süt üretimi arasındaki uçurumu daha da genişletmekte ve genetik olarak NED oluşumunda artış gösterdiği ifade edilmektedir (Patton vd., 2006). Bu dönemde vücut yağ rezervlerinin yaklaşık $\% 60$ '1 doğumdan sonraki ilk haftada da enerji için mobilize olmakta ve vücut rezervlerindeki kayıp ile postpartum adipoz dokulardan yağ mobilizasyonu doğru orantılı geliş̧mektedir (Gillund vd., 2001; Kim ve Suh, 2003; Samanc vd., 2011). Sonuç olarak, VKS'de NEFA ve vücut rezervlerindeki kayıpla birlikte değişiklik göstermektedir (Kadokawa ve Martin, 2006; Knop ve Cernescu, 2009).

Erken laktasyon döneminde enerji dengesinin değerlendirilmesinde, VKS tek başına yeterli bir belirteç olarak görülmemektedir. VKS değerlendirilirken kas ve abdominal dokulardan ziyade deri altı dokulardaki değişimler de gözlemlenmelidir. Erken laktasyon döneminde gerekli enerjiyi sağlamak için yararlanılan kas ve abdominal yağ dokuları (Butler-Hogg vd., 1985), deri altı dokulara göre daha önce toparlanmaktadır. $\mathrm{Bu}$ nedenle hayvan kaybettiği dokuları kazanıp, pozitif enerji dengesinde olsa bile VKS'nin laktasyonun ilerleyen dönemlerinden önce bu tabloyu yansıtmadığ belirtilmektedir (McGuire vd., 2004).

Vücut yağ depolarındaki yıkımlanmaların sona erdiği laktasyon sonrası süreç ve VKS arasındaki ilişkinin incelendiği farklı çalışmalar mevcut olup laktasyonun 8. haftasında (Gibb vd., 1992), vücut kompozisyonun belirlendiği özel bir tekniğe göre laktasyonun 15 . haftasında vücut yağ kompozisyonlarının yerine geldiğ $i$ ve yağ mobilizasyonunun durduğu belirtilmektedir (Komaragiri vd., 1998). McArt vd., (2012) tarafindan prepartum dönemde artan VKS ve NEFA konsantrasyonu ile doğum esnasındaki komplikasyonlar ve postpartum ketozis gelişme riski arasında bir ilişki olduğu saptanmıştır. Diğer bir çalışmada ise doğum esnasında VKS $>3.5$ olan sığırlarda ketozis oluşma riski 
doğum esnasında istenilen VKS (3.25)' ye sahip sığırlara göre daha yüksek bulunmuştur (Gillund vd., 2001; Dann vd., 2006; Roche vd., 2009; Samanc vd., 2011). Ayn1 şekilde doğum öncesi orta (3.25-3.75) ya da yağlı $(\geq 4)$ VKS sahip ineklerde zayıf $(\leq 3.0)$ olanlara göre subklinik ketosiz ve klinik ketozis gelişme riskinin yüksek olduğu tespit edilmiştir (Vanholder vd., 2015).

\section{Materyal ve Yöntem}

\section{Hayvan Materyali}

Araştırmanın hayvan materyalini, Aydın ili Bozdoğan ilçesinde mevcut süt sığırcılığı işletmelerinde yetiştirilen, Adnan Menderes Üniversitesi Veteriner Fakültesi Büyük Hayvan Kliniklerine gelen ve Aydın ili özel işletmelerine kayıtlı 4-6 yaş aralığında ve geçiş döneminde (doğum öncesi-3. haftadan, buzağılama sonrası +3. haftaya kadar olan süreçte) olan 21 baş Siyah Alaca gebe inek oluşturmuştur.

\section{Yöntem}

\section{Kayıtların Değerlendirilmesi ve Grupların Oluşturulması}

Çalışmada Siyah Alaca inekler VKS bakımından da 3 farklı gruba ayrılmıştır: $2<\mathrm{VKS}<3, \quad 3<\mathrm{VKS}<4$ ve $4 \leq \mathrm{VKS}$. Söz konusu gruplar oluşturulmadan önce işletme kayıtları incelenerek hayvan materyalinin kulak numarası, laktasyon sırası ve dönemi ile son buzağılama tarihleri gibi bilgileri kayıt altına alınmıştır.

Deneme hayvanların gruplara dağıtılması kura sistemine (tesadüfî olarak) dayalı olarak yapılmış ve söz konusu grupların laktasyon sırası, laktasyon dönemi ve canlı ağırlık ortalamaları arasındaki farklılıkların istatistiksel olarak önemsiz olması sağlanana kadar kura atışı tekrar edilmiştir.
Bütün bu bilgiler 1şığında söz konusu çalışmada geçiş dönemindeki gebe ineklerde vücut kondisyon skoru ile negatif enerji dengesi arasındaki ilişkinin belirlenmesi amaçlanmıştır.

\section{Vücut Kondisyon SkorununTespiti}

Çalışma kapsamında hayvanların vücut kondisyon skorlaması kuru dönemde (buzağılama öncesi -2 hafta; $15 \pm 2$. günlerde) ve puerperal dönemde (postpartum +2 . haftada; 15 \pm 3 . günlerde) gerçekleştirilmiştir. İneklerin VKS'sinin tespit edilmesinde Edmonson vd., (1989) tarafından geliştirilen ve gözle vücut rezervlerini değerlendirmeye imkân veren yöntemden yararlanılmıştır. Söz konusu yöntemde, serbest halde hareket halinde olan ineklerin bel, kalça ve kuyruk sokumu bölgelerini gözlemlemek suretiyle 1 'den 5'e kadar 0,25 puan aralıkla puanlama gerçekleştirilmektedir.

\section{Serum Biyokimyasal Analizler}

Hayvanlarda negatif enerji dengesinin etkisini belirlemek amaciyla serum biyokimyasal analizler kuru dönemde (buzağılama öncesi -2 hafta; 15 \pm 2 . günlerde) ve puerperal dönemde (buzağılama sonrası +2 . haftada; $15 \pm 3$. günlerde) olmak üzere toplam $2 \mathrm{kez}$ yapılmıştır. Tüm olgularda 2 defaya mahsus olmak üzere vena cephalica antebrachii'den 5 ml'lik antikoagulantsız tüplere alınan kan örnekleri 6000 devir/dk’ da 5 dakika santrifüj edilerek plazmalarına ayrıştırılmıştır. Ayrıştırılan plazmalardan hayvan başı Diaglobal VetPhotometer DP 700 (Diaglobal, Almanya Distribütörü Genartek, Türkiye) cihazında NEFA analizi gerçekleştirilmiştir. İşletme koşullarında yürütülen 
NEFA analizlerine ilişkin bazı görseller aşağıda yer almaktadır (Şekil 1.).
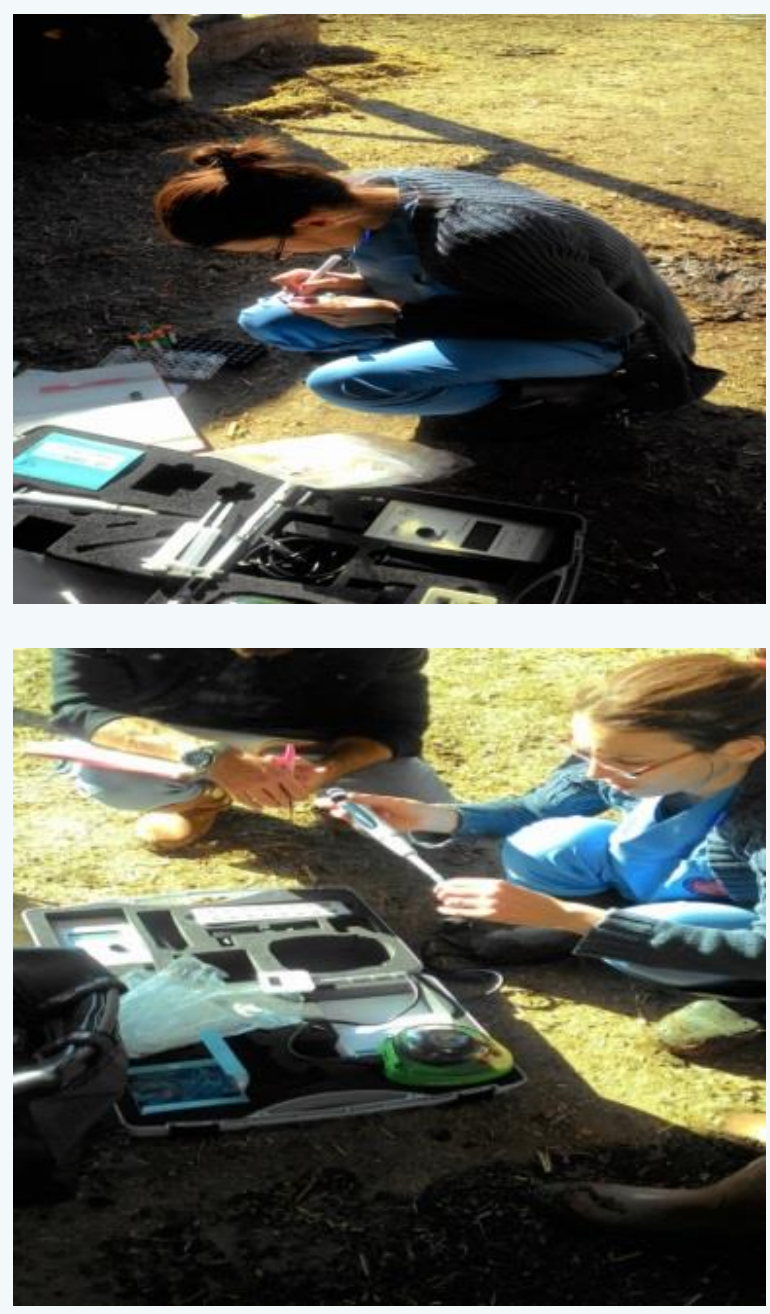

Şekil 1: İşletme koşullarında NEFA analizinin aşamaları Figure 1: NEFA analyses under field conditions.

NEFA analizleri enzimatik kolorimetrik yöntem olan asetilkolin sentetaz-asetil kolin oksidaz enzim reaksiyonu prensinine dayanmaktadır. Plazmadaki NEFA' lar ATP ve koenzim varlığında asetilkolin sentetaz enzim reaksiyonu ile asetil $\mathrm{CoA}^{\prime}$ ya indirgenmekte ve oluşan asetil CoA' larda asetilkolin oksidaz enzimi ile hidrojen peroksite dönüşmektedir. Açığa çıkan hidrojen peroksitlerin mavi-mor renk yoğunluğu plazma da bulunan NEFA konsantrasyonunu göstermektedir. Açığa çıkan renk yoğunluğu Diaglobal VetPhotometer DP 700 (Diaglobal, Almanya
Distribütörü Genartek, Turkiye) cihazında, 520nm dalga boyunda spektrometrik ölçüm ile tespit edilmektedir. Bu bağlamda çalışma kapsamında gerçekleştirilen analizlerde her bir örnek tüpü ile kör ve standart tüpleri küvetlere yerleştirildikten sonra $1000 \mu \mathrm{L}$ R1 çözeltisi eklenmiştir. Ardından $50 \mu \mathrm{L}$ standart solüsyonu standart tüpüne, her bir örneğin plazması $50 \mu \mathrm{L}$ kadar örnek tüplerine ilave edilmiştir. Örnekler 10 dakika inkubasyona bırakılmış ve bekleme süresinin sonunda $500 \mu \mathrm{L}$ R2 çözeltisi tüm tüplere eklenerek ve 10 dakika daha bekletilmiştir. İnkubasyon süresi dolduktan sonra cihazın NEFA ölçüm bölümünde ilk olarak kör tüp ' 0 ' olarak okutulmuştur. Ardından standart tüpü ile absorbsiyon işlemi sağlanmıştır. Standart ve kör tüplerin okutulmasından sonra sırası ile örnekler ardışık olarak cihazın haznesine yerleştirilerek NEFA sonuçları elde edilmiştir.

\section{Verilerin Değerlendirilmesi}

Çalışmadan elde edilen verilerin değerlendirme aşamasında ise, üzerinde durulan özellikler arasında hem olası ilişkilerin hem de farklılıkların ortaya konulmasinda uygun istatistik metotlardan yararlanılmıştır. Bu noktadan hareketle; çalışmada elde edilen verilerin analizi tekrarlanan ölçümlü deneme modeli kullanılarak gerçekleştirilmiştir. Söz konusu model aynı birey üzerinde belirli bir zaman süreci içerisinde, bağımsız değişkenler için birçok kez ölçüm alınması durumunda söz konusudur (Göncü, 2000). Buna ilişkin istatistik model aşağıdaki gibidir:

$$
\begin{aligned}
Y_{i j k l m n}=\mu+a_{i} & +b_{j}+l s_{k}+V k s_{l}+d_{m}+V k s d_{l m} \\
& +\pi_{n(l)}+d \pi_{m n(l)}+e_{i j k l m n}
\end{aligned}
$$

$Y_{\text {iklmn: }}$ i. işletmedeki, j. yaş grubundaki, k. laktasyon sırasındaki, VKS'nin 1. halindeki, m. dönemindeki, n. ineğin buzağılama öncesi esterleşmemiş yağ asidi konsantrasyonu (NEFA),

$\mu$ : populasyon ortalamas1,

$a_{i}$ : i. işletmenin etkisi (i: $\left.1,2,3\right)$ 
$\mathrm{b}_{\mathrm{j}}: \mathrm{j}$. yaş grubunun etkisini $(\mathrm{j}: 4,5,6)$,

$1 \mathrm{~s}_{\mathrm{k}}$ : k. laktasyon sırasının etkisini $(\mathrm{k}: 2,3,4,5,6)$,

vksı: 1. vücut kondisyonu sınıfının etkisi (1: $2<\mathrm{VKS}<3,2$ : $3<\mathrm{VKS}<4,3: 4 \leq \mathrm{VKS})$,

$\mathrm{d}_{\mathrm{m}}: \mathrm{m}$. dönemin etkisi $(\mathrm{m}: 1,2)$

$\pi_{\mathrm{n}(\mathrm{l})}$ :Vks faktörünün l. seviyesindeki yer alan deney ünitesinin rastgele etkisi

vks $d_{l m}$ : interaksiyon etkisi,

$\mathrm{d} \pi_{\mathrm{mn(1)}}$ : vks faktörünün l. seviyesinde yer alan $\mathrm{d}$

faktörü ile deney ünitesi arasındaki

\section{Bulgular}

Çalışmaya dahil edilen hayvanlara ait kan örneklerinden elde edilen esterleşmemiş yağ asidi konsantrasyonlarına (NEFA) ilişkin bulgulara Tablo 1'de yer verilmiştir.

Kuru dönemin son günlerine ve buzağılama öncesinin son 2 haftasina denk gelen pre-partum döneminde yapılan ölçümlerde NEFA konsantrasyonu $0.48 \pm 0.089$ mmol/L olarak, buzağılama sonrası 0 ile 15 günlük süreçte ise $1.01 \pm 0.189 \mathrm{mmol} / \mathrm{L}$ olarak tespit edilmiştir. Gerçekleştirilen ölçümlerde buzağılama sonrası NEFA konsantrasyonunda ciddi bir yükseliş olduğu görülmektedir.

Çalışmada buzağılama öncesi ve buzağılama sonrası dönemlerde VKS gruplarına göre NEFA konsantrasyonundaki değişimler Tablo 2'de özetlenmiştir.

Tablo 2 incelendiğinde buzağılama öncesi dönemde VKS'nin 1. haline karşılık gelen $(2<\mathrm{VKS}<3$ aralığında) hiçbir hayvanın bulunmadığı görülmektedir. Bu durum, grupların belirlenme aşamasının daha önceden de belirtildiği gibi tesadüfi ve kura atışıyla gerçekleştirilmesine rağmen gebeliğin son dönemine çalışma materyalinin 3.25 ile 4.25 aralığında bir VKS ile girmesinden kaynaklanmaktadır. interaksiyon etkisini ve $\mathrm{e}_{\mathrm{ijklmn}}$ : hata terimini ifade etmektedir.

Çalışmadan ele alınan özelliklere ait tanımlayıcı istatistiklerin belirlenmesinde ve varyans analizinde SPSS (SPSS, 2009) isimli programlardan, alt grupların çoklu karşılaştırmalarında ise Duncan Testinden yararlanılmıştır (Duncan, 1995). Buzağılama öncesi ve sonrası VKS ile NEFA değerleri arasındaki korelasyonlar Pearson Korelasyon testi yardımıyla hesaplanmıştır (SPSS, 2009).

Vücut kondüsyon skoru sinıflarına göre NEFA ortalamalarındaki değişimler incelendiğinde, buzağılama öncesi dönemde esterleşmemiş serbest yağ asidi konsantrasyonlarının $0.52 \pm 0.104 \mathrm{mmol} / \mathrm{L}$ ile 0.35 $\pm 0.149 \mathrm{mmol} / \mathrm{L}$ değerleri aldığı görülmektedir. Buzağılama sonrası dönemde ise vücut kondisyonu artan ineklerde NEFA değerlerinde bir artış olduğu tespit edilmiştir. Esterleşmemiş serbest yağ asidi konsantrasyonları üzerine VKS etkisi değerlendirildiğinde ise istatistik bakımdan önemli bir ilişkiye rastlanmamıştır ( $\mathrm{P}>0.05)$. Aynı durum Dönem $\mathrm{X}$ Grup interaksiyonu içinde geçerli olmuştur $(\mathrm{P}>0.05)$.

Esterleşmemiş yağ asidi konsantrasyonu üzerine diğer faktörlerin etkileri araştırıldığında, buzağılama öncesi dönemde yapılan NEFA ölçümleri üzerine işletme faktörünün etkisi istatistik bakımdan önemli $(\mathrm{P}<0.01)$, yaş ve laktasyon sırasının olası etkileri ise önemsiz $(\mathrm{P}>0.05)$ bulunmuştur. Buzağılama sonrası NEFA ölçümleri için benzer bir değerlendirme yapıldığında ise, işletme, yaş ve laktasyon sırasının etkileri istatistik bakımdan önemsiz bulunmuştur $(\mathrm{P}>0.05)$.

Buzağılama öncesi ve sonrası dönemlerde gerçekleştirilen NEFA ölçümleri arasındaki farkların 
genel ortalaması $-0.47 \pm 0.244 \mathrm{mmol} / \mathrm{L}, \mathrm{VKS}$ 'ler için ise $0.27 \pm 0.04$ VKS olarak bulunmuştur. Sonuçlara bakıldığında buzağılama sonrası dönemde esterleşmemiş yağ asidi konsantrasyonlarında ortalama $0.47 \mathrm{mmol} / \mathrm{L}$ 'lik bir artış olurken, VKS'de ise doğum sonrasında çok ciddi bir kondisyon kaybı olmadığı tespit edilmiştir.
VKS ile NEFA arasındaki korelasyonlar daha önceden de belirtildiği gibi Pearson Korelasyon Testi yardımıyla hesaplanmıştır. Yapılan hesaplamalar sonucunda VKS ile NEFA arasında düşük ve negatif yönlü bir korelasyon $(-0.24)$ saptanmıştır $(\mathrm{P}>0.05)$.

\section{Tablo 1. Ortalama Yağ Asidi Konsantrasyonuna Ait Tanımlayıcı İstatistikler}

\section{Table 1. Descriptive statistics of mean fatty acid concentrations}

\begin{tabular}{|c|c|c|c|c|}
\hline \multirow{3}{*}{ Dönemler } & \multicolumn{4}{|c|}{ NEFA (mmol/L) } \\
\hline & & $\bar{X} \pm S_{\bar{X}}$ & En düşük & En yüksek \\
\hline & \multicolumn{4}{|c|}{$* *$} \\
\hline $\begin{array}{l}\text { Buzağılama öncesi -2 hafta; } \\
15 \pm 2 \text {. günlerde }\end{array}$ & 21 & $0.48 \pm 0.089$ & 0.03 & 1.78 \\
\hline $\begin{array}{l}\text { Buzağılama sonrası }+2 . \text { haftada; } \\
15 \pm 3 \text {. günlerde }\end{array}$ & 21 & $1 \pm 0.189$ & 0.01 & 3.00 \\
\hline
\end{tabular}

Tablo 2. Dönemler İçi VKS Sınıflarına Göre Ortalama Esterleşmemiş Serbest Yağ Asidi Konsantrasyonuna Ait Tanımlayıcı İstatistikler

Table 2. Descriptive Statistics for Mean Non-Esterified Free Fatty Acid Concentration by BCS Classes in the Periods

\begin{tabular}{|c|c|c|c|c|}
\hline Dönemler & VKS sinıfları & $\mathrm{N}$ & NEFA (mmol/L) & $p$ \\
\hline Buzağılama öncesi -2 hafta; & $3<\mathrm{VKS}<4$ & 17 & $0.52 \pm 0.104$ & Ö.D \\
\hline $15 \pm 2$. günlerde & $4 \leq \mathrm{VKS}$ & 4 & $0.35 \pm 0.149$ & Ö.D \\
\hline Buzağılama sonrası +2 . haftada; & $2<\mathrm{VKS}<3$ & 4 & $0.91 \pm 0.646$ & Ö.D \\
\hline $15 \pm 3$. günlerde & $3<\mathrm{VKS}<4$ & 14 & $0.93 \pm 0.230$ & Ö.D \\
\hline & $4 \leq \mathrm{VKS}$ & 3 & $1.15 \pm 0.462$ & Ö.D \\
\hline
\end{tabular}

a,b,c: Her değişkene ait alt gruplar arasında aynı satırda farklı harf taşıyan ortalamalar arası farklar önemlidir: *: $\mathrm{P}<0.05$; **: $\mathrm{P}<0.01$, Ö.D.: Önemli Değil

\section{Tartışma ve Sonuç}

Vücut kondisyon skorundaki değişimler ile NEFA, geçiş dönemi boyunca lipomobilizasyonu ölçmek için iyi göstergelerdir (Chapel vd., 2017). Geçiş dönemindeki süt sığırlarında enerji gereksinimi (süt üretimi için gerekli olan) enerji alınımını aştığı zaman NED karşımıza çıkmaktadır (Arslan ve Tufan, 2015). Buzağılama öncesi dönem süresince süt ineklerinin enerji durumu sıklıkla değerlendirilmekte olunup bu durum enerji gereksinimleri ile enerji alımları dengesine dayanmaktadır (Grummer ve Rastani, 2003). 
Serum NEFA düzeyinin yükselmesi postpartum süt sığırlarında NED'in göstergelerinden biridir. NED'in diğer göstergeleri; plazma beta-hidroksibütirat seviyendeki artış, plazma glukoz konsantrasyonunda, insülin ve insülin büyüme faktöründe, plazma leptin konsantrasyonundaki azalış ile karaciğerde triasilgliserol birikimine bağlı yağlı karaciğer (Drackley, 1999) ve vücut kondisyon skorunda düşüş olarak sayılabilmektedir.

Çalışmamızda, NEFA konsantrasyonu buzağılama öncesi süreçte $0.48 \pm 0.089 \mathrm{mmol} / \mathrm{L}(0-15$ gün) ve buzağılama sonrası 0 ile 15 günlük süreçte ise $1.01 \pm$ $0.189 \mathrm{mmol} / \mathrm{L}$ olarak hesaplanmıştır. Chalmeh vd., (2015) çalışmalarında erken laktasyondaki NEFA konsantrasyonunu $0.34 \pm 0.01 \mathrm{mmol}$ ve geç laktasyonda ise $0.24 \pm 0.01 \mathrm{mmol}$ olarak tespit etmişlerdir. Sheehy vd., (2016) buzağılama öncesi 15 günde vücut kondüsyonundaki artış ya da azalışı ve bu değişimin serum metabolik ve üretimle ilişkisini irdelemişlerdir. Prepartum NEFA konsantrasyonu VKS kaybeden ve kazanan inekler arasında karşılaştırılmış ve her iki grupta Mulligan vd., (2016) tarafindan prepartum negatif metabolik durum ve serum konsantrasyonunu gösteren $0.4 \mathrm{mmol} / \mathrm{L}$ ve postpartum için $0.7 \mathrm{mmol} / \mathrm{L}$ eşik değerini geçtiği tespit edilmiştir. Bu bağlamda, bizim çalışmamızda elde ettiğimiz bulgular da Sheehy vd., (2016) 'nın bulgularına benzerlik göstermiştir. Serum NEFA konsantrasyonları laktasyonun erken dönemi süresince prepartum değerlerine göre yüksek seyir etmiştir. Chapel vd., (2017)'nin çalışmalarında da benzer şekilde prepartum dönemde VKS'si 3.75 ve daha yukarıda olan ineklerin serum NEFA değerleri 0.495 mmol/L'den yüksek bulunmuştur.

Barletta vd., (2017) tarafindan buzağılama öncesi 21 günden buzağılama sonrası 21 güne kadar olan dönemde 3 farklı VKS grubunda (kondisyon kaybeden, sabit kondisyonlu ve kondisyon kazanmış) NEFA konsantrasyonları sirasiyla $0.51 \mathrm{mmol} / \mathrm{L}, 0.45 \mathrm{mmol} / \mathrm{L}$ ve $0.42 \mathrm{mmol} / \mathrm{L}$ olarak bulunmuş olup, özellikle buzağılama sonrası 7 günde NEFA konsantrasyonlarında yükselme gözlenmiştir.

Sheehy vd., (2016) buzağılama öncesi 15 günlük periyotta VKS kaybeden ineklerde kondüsyon artışı olan diğer hayvanlara nazaran NEFA konsantrasyonunda yükselme eğilimi olduğunu tespit etmişlerdir. Bizim çalışmamızda ise buzağılama sonrası 15 günlük dönemde VKS artışına paralel olarak NEFA konsantrasyonlarında bir artış söz konusu olmuştur.

Buzağılama öncesi ve sonrası dönemde görülen VKS değişimleri, ineklerin genotipleri ile sürü yönetim sistemine bağlı olarak işletmeden işletmeye farklılık göstermektedir (Sheehy vd., 2016) Çalışmamızda her iki dönemde yapılan değerlendirmeler sonucunda elde edilen VKS'ler arasında $0.27^{\prime}$ 'lik bir düşüş söz konusu olmuştur. Söz konusu azalma, Sheehy vd., (2016)'nın çalışmalarında ise 0.29 birim olarak bildirilmiştir. Bildiğimiz kadarıyla, yakın kuru dönem olarak adlandırılan ve beklenen buzağılama tarihinden önceki son üç haftayı içine alan dönemde VKS kaybı olan ineklerin metabolik durumunu ile erken laktasyon üretkenliği arasındaki ilişkiyi açıklayan herhangi bir literatür bulunmamaktadır. Söz konusu süre zarfinda VKS kaybı, yetersiz beslenme veya kötü yönetim sebebiyle veya geç kuru dönemde uygulanan kontrollü enerji besleme stratejisi nedeniyle ortaya çıkabilmektedir (Dann vd., 2006; Roche, 2006; Cardoso vd., 2013). Pre ve postpartumdaki metabolik durum ve üretim parametreleri üzerine geçiş dönemindeki VKS kaybının postpartumdaki sonuçları bilinmemektedir (Sheehy vd., 2016).

Literatürde yüksek postpartum NEFA konsantrasyonunun üretim (McArt vd., 2013), üreme (Leroy vd., 2008) ve sağlık (Hammon vd., 2006) 
açısından olumsuz sonuçlara yol açtığı ile ilgili birçok rapor olduğu göz önüne alındığında, özellikle prepartum dönemde BCS kaybının da bu tarz sonuçlara sebebiyet vermesi dikkat çekicidir (Sheehy vd., 2016). Keza, uzak kuru dönemde kontrollü bir beslenme stratejisinin (günlük gereksinimlerin \%80 ile \%100'ü) postpartum dönemdeki serum NEFA konsantrasyonları üzerine önemli bir azalmaya neden olduğu, ancak yakın kuru dönemde kontrollü enerji diyetleri ile beslemenin buzağılama öncesi serum NEFA konsantrasyonlarını yükselttiği bildirilmiştir (Cardoso vd., 2013; Drackley ve Cardoso, 2014).

Benzer şekilde, Keogh vd., (2008) tarafından gebeliğin son döneminde düşük ya da yüksek enerjili beslenen ineklerin postpartum periyodunda serum NEFA konsantrasyonlarında artış eğilimi olduğu tespit edilmiştir. Benzer şekilde, bizim çalışmamızda da buzağılama sonrası dönemde serum NEFA konsantrasyonunda ortalama $0.47 \mathrm{mmol} / \mathrm{L}$ 'lik bir artış söz konusu olmuştur.

\section{Kaynaklar}

Amaral-Phillips, DM. (2010). Tools for diagnosing nutritional problems in dairy herds, https://afs.ca.uky.edu/files/tools_for_diagnosing_nutritional _problems_in_dairy_herds.pdf. Erişim Tarihi: Şubat 2018.

Arslan, C., Tufan, T. (2015). Süt ineklerinin beslenmesi I. Bu dönemde görülen fizyolojik, hormonal, metabolik ve immünolojik değişiklikler ile beslenme ihtiyaçları. Kafkas Univ Vet Fak Derg, 16(1), 151-158.

Ayaşan, T., Asarkaya, A., Hızlı, H., Gök, K., Tekgül, A., Karakozak, E., Kara, U., Seğmenoğlu, M.S., Çoban, S., Mutlu, H., Kılıçalp, N. (2012). Siyah Alaca ineklerde vücut kondisyon skorunun embriyo kalitesine etkisi. Kafkas Univ Vet Fak Derg 18(1), 91-94.
Sonuç olarak, literatürel bilgi dahilinde geçiş dönemi ineklerin üretim döngüsünün önemli bir unsuru olduğu muhakkaktır. Bu çalışmada, buzağılama öncesi 15 günlük dönemdeki vücut kondüsyonundaki artışın yanı sira serum NEFA konsantrasyonu ile arasinda istatistiksel öneme haiz olmayan negatif bir ilişki olduğu, buzağılama sonrası dönemde ise vücut kondisyonundaki artış ile serum NEFA konsantrasyonundaki artışın paralellik gösterdiği tespit edilmiştir. Literatürde belirtildiği gibi, buzağılama öncesi 15 günlük süreçte vücut kondisyon kaybı olan ineklerin potansiyel üretim ve sağlık durumlarında azalmaya neden olacağına işaret edilmiştir. Bu noktadan hareketle, farklı fizyolojik yapı sergileyen ineklerin mevcut metabolik profili değerlendirilerek enerji dengelerinin tespit edilmesi ve bu şekilde bazı metabolik ve üretim problemlerinin önüne geçilmesi mümkün olabilir.

\section{Teşekkür}

$\mathrm{Bu}$ çalışma Adnan Menderes Üniversitesi Bilimsel Araştırma Projeleri Birimi tarafindan (BAP No: BOMYO-17001) desteklenmiştir.

Barletta, R.V., Maturana, M., Carvalho,. PD., Del Valle, T..A, Netto, A.S., Rennó, F.P., Mingoti, R.D., Gandra, J.R., Mourão, G.B., Fricke, P.M., Sartori, R., Madureira, E.H., Wiltbank, M.C. (2017). Association of changes among body condition score during the transition period with NEFA and BHBA concentrations, milk production, fertility, and health of Holstein cows. Theriogenology, 104, 30-36.

Bellows, D.S., Ott, S.L., Bellows, R.A. (2002). Review: Cost of reproductive disease, and conditions in cattle. The Prof Anim Sci, 18, 26-32.

Bobe, G., Young, J.W., Beitz, D.C. (2004). Invited review: pathology, etiology, prevention, and treatment of fatty liver in dairy cows. J Dairy Sci, 87, 3105-3124. 
Butler, W.R. (1998). Effect of protein nutrition on ovarian and uterine physiology in dairy cattle. J Dairy Sci, 81, 2533-2539.

Butler-Hogg, B.W., Wood, J.D., Bines, J. (1985). Fat partitioning in british friesian cows: the influence of physiological state on dissected body composition. J Agric Sci, 104, 519-528.

Cardoso, F.C., LeBlanc, S.J., Murphy, M.R., Drackley, J.K. (2013). Prepartum nutirional strategy effects reproductive performance in dairy cows. J Dairy Sci, 96, 5859-5871.

Chalmeh, A., Pourjafar, M., Nazifi, S., Momenifar, F., Mohamadı, M. (2015). Circulating Metabolic Profile of High Producing Holstein Dairy Cows. J Fac Vet Med Istanbul Univ, 41(2), 172-176.

Chapel, J.M, Rumino, R., Pereira, V., Benedito, J.L. (2017). Relationship of BCS prepartum with reproductive performance and lipomobilization in Holstein dairy cows. Pak Vet J, 37(2), 215-219.

Coşkun, B. (1997). Süt ineklerinin beslenmesi. In: Şeker E., İnal F. (ed's). Hayvan Besleme. 1st ed. Selçuk Üniversitesi Veteriner Fakültesi Yayın Ünitesi, 1-59.

Çitil, M., Uzlu, E. (2005). Sığırlarda doğum sonrası hastalıkların erken tanısında ultrasonografik yöntemle vücut kondisyon skor tayinin önemi. Kafkas Üniversitesi Veteriner Fakültesi Dergisi, 11(2), 201-206.

Dann, H.M,, Litherland, N.B., Underwood, G.P., Douglas, G., Drackley, J.K. (2006). Diets during far-off and close-up dry periods affect periparturient metabolism and lactation in multiparous cows. J Dairy Sci, 89, 3563-3577.

Defra (2001). Condition scoring of dairy cows. Animal Health and Welfare, Department of Environment, Food and Rural Affairs, 1-12. www.defra.gov.uk/corporate/ publications/pubf rm.htm, 2001.

Drackley, J.K. (1999). Biology of dairy cows during the transition period: The final frontier?. J Dairy Sci, 82, 22592273.

Drackley, J.K., Cardoso, F.C. (2014). Prepartum and postpartum nutritional management to optimise fertility in high-yielding dairy cows in confined TMR systems. Anim, $8,5-14$.

Duncan, D.B. (1995). Multiple range and multiple $F$ test. Biometrics, 11, 42.
Edmonson, A.J., Lean, I.J., Weaver, L.D., Farver, T., Webster, G. (1989). A body condition scoring chart for Holstein dairy cows. J Dairy Sci 72, 68-78.

Gibb, M.J., Ivings, M.E., Dhanoa, M.S., Sutton, J.D. (1992). Changes in body components of autumn-calving HolsteinFriesian cows over the first 29 weeks of lactation. Anim Product, 55, 339-360.

Gillund, P., Reksen, O., Gröhn, Y.T., Karlberg, K. (2001). Body condition related to ketosis and reproductive performance in Norwegian dairy cows. J Dairy Sci, 84, 13901396.

Gong, J.G. (2002). Influence of metabolic hormones and nutrition on ovarian follicle development in cattle: Practical Implications. Domest Anim Endocrinol, 23, 229-241.

Görgülü, M., Göncü, S., Serbester, U., Kıyma, Z. (2011). Süt sığırlarının üremesinde beslemenin rolü. 7. Ulusal Zootekni Bilim Kongresi, Adana.

Göncü, S. (2000): Adana Entansif Süt Sığırcılığ1 İşletmelerinde Yetiştirilen Saf ve Melez Siyah Alaca İnek Sütlerinde Somatik Hücre Sayısına Etki Eden Faktörler ve Mastitis ile İlişkisi. Doktora Tezi

Adana.Grummer, R.R., Rastani, R.R. (2003). When should lactating cows reach positive energy balance? Prof Anim Sci, 19, 197-203.

Gumen, A., Keskin, A., Yilmazbas-Mecitoglu, G., Karakaya, E., Wiltbank., M.C. (2011). Dry period management and optimization of postpartum reproductive management in dairy cattle. Reproduction of Domestic Animals, 46, 11-17.

Hammon, D.S., Evjen, I.M., Dhiman, T.R, Goff, J.P. (2006). Neutrophil function and energy status in Holsteins cows with uterine health disorders. Vet Immunol Immunopathol, 113, 21-29.

Kadokawa, H., Martin, B.G. (2006). A new perspective on management of reproduction in dairy cows: the need for detailed metabolic information, an improved selection index and extended lactation. J Reprod Dev, 52(1), 61-168.

Kehrli, M.E., Neill, J.D., Burvenich, C., Goff, J.P., Lippolis, J.D., Reinhardt, T.A., Nonnecke, B.J. (2006). Energy and protein effects on the immune system. In: Sejrsen K, Hvelplund T, Nielsen MO (Ed's). Ruminant physiology: Digestion, metabolism and impact of nutrition on gene 
expression, immunology, and stress. 1st ed. Wagenigen, Academic Publishers, 459-61.

Kellogg, W. (2014). Body condition scoring with dairy cattle, http://www.uaex.edu/ other_Areas/Publications/PDF/FSA4008.pdf, 1914. Erişim Tarihi: Şubat 2018.

Keogh, B.K., French, P., Mcgrath, T., Storey, T., Mulligan, F.J. (2008). Effect of forage allowance and forage system during the dry period on the performance of dairy cows. Proceedings of the New Zealand Society of Animal Production, 16-19.

Kim, H.I., Suh, G.K. (2003). Effect of the amount of body condition loss from the dry to near calving periods on the subsequent body condition change, occurrence of postpartum diseases, metabolic parameters and reproductive performance in holstein dairy cows. Theriogenology, 60, 1445-1456.

Knop, R., Cernescu, H. (2009). Effects of negative energy balance on reproduction in dairy cows. Lucrărı Stınłıfice Medicină Veterınară, 2, 198-205.

Komaragiri, M.V.S., Casper, D.P., Erdman, R.A. (1998). Factors affecting body tissue mobilization in early lactation dairy cows. 2. effect of dietary fat on mobilization of body fat and protein. J Dairy Sci, 81, 169-175.

LeBlanc, S. (2010). Monitoring metabolic health of dairy cattle in the transition period. J Reprod Dev, 56, 29-35.

Leslie, K., Duffield, T., LeBlanc, S. (2004). Monitoring and managing energy balance in the transition dairy cow. Minnesota Dairy Health Conference, Bloomington, Minnesota.

Lopez, H., Satter, L.D., Wiltbank, M.C. (2004). Relationship between Level of Milk Production and Estrous Behavior of Lactating Dairy Cows. Anim Reprod Sci, 81, 209-223.

Leroy, J., Van Soom, A., Opsomer, G., Bols, P.E.J. (2008). The consequences of metabolic changes in high-yielding dairy cows on oocyte and embryo quality. Anim, 2, 11201127.

McArt, J.A.A., Nydam, D.V., Oetzel, G.R, (2012). Dry period and parturient predictors of early lactation Hyperketonemia in Dairy Cattle. J Dairy Sci, 96(1), 198-209. McArt, J.A.A., Nydam, D.V., Oetzel, G.R. (2013). Overton TR, Ospina PA. Elevated non-esterified fatty acids and $\beta$ - hydroxybutyrate and their association with transition dairy cow performance. Vet J, 198, 560-570.

McGuire, M.A., Theurer, M., Vicini, J.L., Crooker, B. (2004). Controlling Energy Balance in Early Lactation. Advances in Dairy Technology, 16, 241.

Mulligan, F., O’Grady, L., Rice, D., Doherty, M. (2006). Production disease of the transition cow; body condition score and energy balance. Ir Vet J, 59, 505-510.

Mwaanga, E.S., Janowski, T. (2000). Anoestrus in dairy cows: causes, prevalence and clinical forms. Reprod Domest Anim, 35, 193-200.

Oltenacu, P.A. (2007). Health and welfare in genetically high producing dairy cows and its economical implications. XIII ISAH Congress, Tortu, Estonia.

Patton, J., Kenny, D.A., Mee, J.F., O'Mara, F.P., Wathes, D.C., Cook, M., Murphy, J.J. (2006). Effect of milking frequency and diet on milk production, energy balance, and reproduction in dairy cows. J Dairy Sci, 89(5), 1478-87.

Roche, J.F., Macke,y D., Diskin, M.D. (2000). Reproductive management of postpartum cows. Anim Reprod Sci, 60-61, 703-712.

Roche, J.F. (2006). The effect of nutritional management of the dairy cow on reproductive efficiency. Anim Reprod Sci, 96, 282-296.

Roche, J.R., Friggens, N.C., Kay, J.K., Fisher, M.W., Stafford, K.J., Berry, D.P. (2009). Invited review: body condition score and its association with dairy cow productivity, health, and welfare. J Dairy Sci, 92, 5769-5801.

Samanc, H., Danıjela, K., Stojic, V., Dragıca, S., Vujanac, I., Prodanovic, R., Slavica, B. (2011). Application of the metabolic profile test in the prediction and diagnosis of fatty liver in Holstein Cows. Acta Vet Scand, 61(5-6), 543-553.

Sheehy, M.R., Fahey, A.G., Aungier, S.P.M., Carter, F., Crowe, M.A., Mulligan, F.J. (2016). A comparison of serum metabolic and production profiles of dairy cows that maintained or lost body condition 15 days before calving. $\mathbf{J}$ Dairy Sci, 100, 1-12.

Silke, V., Diskin, M.G., Kenny, D.A., Boland, M.P., Dillon, P., Mee, J.F., Sreenan, J.M. (2002). Extent, pattern and factors associated with late embryonic loss in dairy cows. Anim Reprod Sci, 71, 1-12. 
Silvia, W.J. (1998). Changes in reproductive performance of holstein dairy cows in Kentucky from 1972 to 1996. J Dairy Sci, 81(1), 244.

Suriyasathaporn, W., Daemen, A.J.J.M., NoordhuizenStassen, E.N., Dieleman, S..J, Nielen, M., Schukken, Y.H. (1999). $\beta$-Hydroxybutyrate levels in peripheral blood and ketone bodies supplemented in culture media affect the in vitro chemotaxis of bovine leukocytes. Vet Appl Environ Microbiol,v68, 177-186.

SPSS (2009). SPSS release 18.0.0, Standard version for windows. Steel RDG, Torrie JH Principles and procedures of statistics. Mc-Graw Hill Book Co. Inc. ; New York, USA.

Tamminga, S., Luteijn, P.A., Meijer, R.G.M. (1997). Changes in composition and energy content of liveweight loss in dairy cows with time after parturition. Livest Prod Sci, $52,31-38$.

Vanholder, T., Papen, J., Bemers, R., Vertenten, G., Berge, A.C.B. (2015). Risk factors for subclinical and clinical ketosis and association with production parameters in dairy cows in the Netherlands. J Dairy Sci, 98(2), 880-888.

Varışl,, Ö., Tekin, N. (2011). Holştayn ineklerde vücut kondisyon skorunun fertilite ve bazı reprodüktif parametrelere etkisi. Ankara Üniv Vet Fak Derg, 58, 111115.

Yaylak, E., Kaya, A. (2000). Süt sığırcılığında vücut kondisyon puanı ve önemi. Hayvansal Üretim, 41, 29-37.

Washburn, S.P., Silvia, W.J., Brown, C.H., McDaniel, B.T., McAllister A.J. (2002). Trends in reproductive performance in southeastern Holstein and Jersey DHI Herds. J Dairy Sci, 84, 244-251.

Wiltbank, M., Lopez, H., Sartori, R., Sangsritavong, S., Gumen, A. (2006). Changes in Reproductive Physiology of Lactating Dairy Cows due to Elevated Steroid Metabolism. Theriogenology, 65, 17-29. 